\title{
Several Characteristics Of The Special International Court For Kosovo
}

\author{
Azem Hajdari \\ Faculty of Law, University of Prishtina “Hasan Prishtina”, Prishtina, Kosovo \\ doi: 10.19044/esj.2016.v12n19p147 URL:http://dx.doi.org/10.19044/esj.2016.v12n19p147
}

\begin{abstract}
The Special International Court for Kosovo (hereinafter the Special Court) has been established for adjudication of cross-border and international crimes alleged to have been committed in Kosovo during the period of time January 1, 1998-December 31, 2000. This court consists of Specialized Chambers and the Office of Specialized Prosecutor and they shall be able to conduct investigations, criminal prosecutions and trials of persons alleged to have committed war crimes and crimes against humanity. The Special Court shall perform its activities in Kosovo and in The Kingdom of Netherlands. This court has in its focus the adjudication of crimes included in the Report of the Parliamentary Assembly of the Council of Europe DOK 12462 dated January 7, 2011, crimes reported by Swiss Senator Dick Marty. The Special Court is expected to solve the sustainability of charges on organ trafficking and other serious crimes committed by influential individuals within former KLA, charges which shall be considered a great obstacle in developing and integrating Kosovo processes. In this short scientific paper shall be discussed about the meaning of The Special Court, its jurisdiction, punishments, their execution, the cooperation of this court with national and international institutions etc.
\end{abstract}

Keywords: Kosovo, Court, Special, Jurisdiction, Specialized Chambers, The Office of Specialized Prosecutor, Kosovo

\section{Introduction}

The Special Court has been established by the Law No. no. 05 / L053 of the Kosovo Assembly on Specialized Chambers and The Office of Specialized Prosecutor. This is a court which as its local element has only its founding act. All other elements characterizing this court are of international nature, so it can be easily called International Special Court for Kosovo.

The Special Court has been established for adjudicating war crimes, crimes against humanity and other crimes committed in Kosovo during the 
period of time January 1, 1998-December 31, 2000. It is about crimes linked to those presented in the Report of the Parliamentary Assembly of the Council of Europe DOK 12462 dated January 7, 2011 which have been the object of criminal ivestigation conducted by the Special Investigative Task Force of the Special Prosecution of the Republic of Kosovo. The Special Court is a sui generis court. This among other things also due to the fact a) shall have Specialized Chambers and the Office of Specialized Prosecutor in level of all Kosovo Courts and in the Kingdom of Netherlands; b) shall be composed only by international judges (although operating in Kosovo); and c) shall face Kosovo with international justice twice (after ICTY). Although the need for the establishment of this court could have resulted as a necessity, I consider these and other elements characterizing it constitute an evident injustice that international community is doing to Kosovo and its people. This Court shall be able to impose punishments by imprisonment, including life imprisonment sentence, punishment by fine and the measure of confiscating assets. Punishments by imprisonment of this court shall be executed in the third places in accordance to their legislation, but they shall not be able to shorten their duration.

\section{The meaning of the Special Court}

The Kosovo Special Court was established by the Law No. 05 / L$053 .^{55}$ This law has been issued by Kosovo Assembly which provides a type of local authorship of this court, and uses the designation of specialized chambers and the office of specialized prosecutor. In fact, the issuance of the Law on the Special Court by the Kosovo Assembly is considered to be the only element which gives to this court a type of attribute of Kosovo state character. The Special Court was established on purpose to fulfill Kosovo international obligations foreseen by the Law No. 04/L-274 to guarantee the protection of fundamental rights and freedoms guaranteed by the Constitution of the Republic of Kosovo as well as to guarantee safe, independent, impartial, fair and effective criminal proceedings concerning cross-border and international alleged serious crimes committed during the period of time January 1, 1998-December 31, 2000, crimes linked to those presented in the Report of the Parliamentary Assembly of the Council of Europe DOK 12462 dated January 7, 2011 which have been object of criminal ivestigation conducted by the Special Investigative Task Force of the Special Prosecutor of the Republic of Kosovo. The Special Court through the Office of Specialized Prosecutor and its Specialized Chambers has all the necessary authorizations related to criminal prosecutions, trials and the

\footnotetext{
${ }^{55}$ This law was promulgated by President of Kosovo decree No. DL-027/2015, date August 20, 2015 and entered into force on September 5, 2015.
} 
execution of imposed judgments concerning crimes for which was established.

As it results, this court has the responsibility to judge cross-border and international crimes alleged to have been committed in Kosovo during the war and post-war period.

For the operationalization of work of the Special Court, Kosovo and the Kingdom of Netherlands have bound a special agreement. This is referred to as The Interim Agreement on the Organisation of the Institution of Kosovo Special Court and its relocation to the Netherlands. ${ }^{56}$ This agreement was signed by the former Minister of Foreign Affairs and the Ambassador of the Kingdom of Netherlands in Kosovo Gerrie Willems and it has been decreed by the Decree of the former President of Kosovo Atifete Jahjaga No. DMN-003-2016. This agreement (and the relevant law) provides that the Special Court shall have its headquarter besides in Kosovo as well as in the Kingdom of Netherlands.

In fact, the idea of the Special Court establishment began its journey five years ago (in 2010), when Kosovo opinion was shocked by the hypotheses that members of KLA had committed crimes against Serb civilians, by violating war rules, including organ trafficking. ${ }^{57}$ Kosovo opinion was shocked due to the fact with this topic dealt the most prestigious information media in Europe, including the British newspaper The Guardian which proclaimed Hashim Thaqi and persons close to him having a major role in criminal activities related with the period of war and a number of developments after the war. ${ }^{58}$

To the idea of Special Court establishment significantly contributed also the fact of international justice institutions failure operating in Kosovo (first $\mathrm{UNMIK}^{59}$ and then $\mathrm{EULEX}^{60}$ ) and local penal justice institutions

${ }^{56}$ This agreement establishes favorable conditions on stability and independence of the Special Court institution and facilitates its efficient functioning in the Kingdom of Netherlands.

${ }^{57}$ Koha.net//?id=27§=69212. These hypotheses had set up Swiss senator Dick Marty, in his report on organ trafficking by the KLA, which accused the former political leader of the KLA Hashim Thaqi as a head of mafia group in smuggling weapons, drugs and human organs in throughout Eastern Europe. These charges become official on January 25, 2011, upon approval of the Parliamentary Assembly of the Council of Europe Resolution. This resolution which was supported by the majority of senators of the Parliamentary Assembly of the Council of Europe (only 8 senator had voted against) requested investigations on trafficking organs in Kosovo and in north of Albania.

${ }^{58}$ Ibid.

${ }^{59}$ See more: Hajdari Azem, Certain Successes and Failures of the UN Mission in Kosovo in Managing the Criminal Justice System, S T U D I A, UNIVERSITATIS BABEŞ-BOLYAI, POLITICA, No.1, 2008, pg. 109.

60 Hajdari Azem, THE FUNCTIONALIZATION ROLE OF CRIMINAL JUSTICE SYSTEM 
(police, state prosecution and courts) to prosecute and adjudicate persons which were alleged to have committed cross-border and international crimes during the war and post-war period in Kosovo. To reinforce the idea for the Special Court establishment undoubtedly had contributed also the unwillingness of governments who governed Kosovo in post-war period in order to establish functional respective mechanisms (prosecution and courts) that would prosecute and adjudicate complex and complicated criminal cases during the war and post-war period. Of course, the impact it might have come as a result of responsible institutions inability of the country to establish a criminal justice system extending throughout the country, ${ }^{61}$ fair, efficient and politically not influenced. Consequently these and probably other factors have dictated the necessity for establishment of the Special Court.

Despite of the fact that have existed factors, even with substantial impact, in advancing the idea for establishment of the Special Court, I consider in political terms as well as in practical one, to Kosovo and its people by establishment of this court is done an injustice which strikes Kosovo Albanian people and stigmatizes its liberation war during the years 1998-1999. By establishing act of the Special Court the international community as was not satisfied upon the fact of several KLA commanders facing the Tribunal of Hague for former Yugoslavia and the punishment of some others from Serbian courts all over Serbia. In fact this is the first case in the history of mankind through which the international community for the second time puts in the bench of defendants military of a country who protected himself $^{62}$ in meanwhile leaves without penal treatment (through another special court) members of Serbian army and police ( the aggressor army) for atrocities committed everywhere in former Yugoslav Federation, including Kosovo.

Finally, I would like to clarify to professional and public opinion, that under no circumstances I do not prefer to protect crime and criminals. They shall be punished everytime for the committed crimes, regardless of the fact

ESTABLISHING SUSTAINABLE PEACE IN KOSOVO AND BALKAN REGION, AMERICAN RESEARCH THOUGHTS, Volume 1, Issue 2, 2014, pg. 1004 - 1011.

${ }^{61}$ See more: Hajdari Azem dhe Albulena Hajdari, Functionalityof the Criminal Justice System in Kosovo, with Special Focusof the Northern Partof the Country, in the Lightof the Agreemento fBrusselsof 19 April, 2013 for the Normalizationof the Relations between Kosovo and Serbia, EUROPEAN ACADEMIC RESEARCH, Vol. I, Issue 12/ March 2014, pg. $5355-5361$.

${ }^{62}$ Although charges by Dick Marty address to former KLA responsible, the Special Court should not have luxury and courage to do one-national trials. This due to the fact of commission numerous and terrible crimes (about 15.000 thousands people killed,...,) that Serbian army and police committed against defenseless Albanian population during the war in Kosovo. 
they are linked to the state of war or peace, and the victims of crimes shall be compensated for consequences which they face from aggresive actions of criminals. But, nor morally or professionally I cannot be indifferent to the reality of the Special Court establishment, through which the international community created a dangerous precedent of punishing a protective and victim of war country and creation of favors to the aggressor state.

\section{Basic principles of the Special Court activities}

Principles represent basic rules, basic guidelines, respectively rails upon which is built and function the justice institutions. ${ }^{63}$ The work of the Special Court is based in a considerable number of principles. "Some of these principles belong to a legal system regulation in general, whereas some others are simply criminal proceedings principles. "64 In the following, shall be handled some of the most important principles related to activities of this court.

\section{The principle of legality}

The principle of legality implies the mandatory respect and enforcement of legal provisions by means of which has been regulated the Special Court activity. This principle observed under the article 3 of the Law on Specialized Chambers and the Office of Specialized Prosecutor is manifested in obligation of the Special Court to adjudicate and work in accordance with the Constitution of the Republic of Kosovo, this law as lex specialis, other Kosovo law provisions included in this law, customary international law to which has been given precedence over domestic laws by article 19 (2) of Kosovo Constitution, and international law of human rights determining the standards of criminal justice, including the European Convention on Human Rights and Fundamental Freedoms and the International Covenant on Civil and Political Rights, which was given precedence over domestic laws with the article 22 of Kosovo Constitution.

Specific in relation to the manifestation of principle of legality in the work of the Special Court represents the solution provided in the article 3 paragraph 3 of the Law on Specialized Chambers and the Office of Specialized Prosecutor according to which judges of this court in adjudicating alleged crimes by this law shall be helped by international law sources, including secondary sources such as jurisprudence from ad hoc international tribunals, International Criminal Court and other criminal courts.

\footnotetext{
${ }^{63}$ Hajdari Azem, Criminal Procedure Law, General Part, Prishtina, 2014, pg. 57.

${ }^{64}$ Compare: Sahiti Ejup §Murati Rexhep Criminal Procedure Law, General Part, Prishtina, 2014, pg. 89.
} 
Observed in the context of principle of legality, when it comes to procedure before the Special Court, this law makes it clear the fact of its priority in relation to any law or by-law enforced in Kosovo which addresses substantial criminal cases, procedural or execution of criminal sanctions. Consequently, the principle of legality in relation to the Special Court has manifested an extent that in a way or another represents a precedent to the Kosovo justice system. ${ }^{65}$

\section{The principle of individual criminal liability}

In modern times, within international criminal law and domestic state laws has been installed the principle of individual criminal liability. This is a basic principle also conerning the Special Court work.

"Consequently, a person shall be considered criminally liable if in the time of commission of criminal offence possessed certain mental capacity and if to him had existed a particular relation toward the offence which he had committed. In other words, a person shall be considered criminally liable if in the time of commission of criminal offence has been responsible and guilty." 66

Crimes against humanity, war crimes and other crimes according to Kosovo law specified in articles 13, 14 and 15 of the Law on Specialized Chambers and the Office of Specialized Prosecutor shall be committed only by direct intent, and in certain cases also by eventual intent (for instance murders, bodily harm etc.). ${ }^{67}$ Despite this, it must be emphasized that for criminal liability, when it comes to these crimes, it shall not be required for the perpetrator to have been aware that his actions violate international law rules, because the violation of these rules represents the only cause of the one objective condition of punishment. ${ }^{68}$ Negligence as a form of guilt to these crimes does not represent a base for criminal liability.

Consequently, in order for a person to become a subject of criminal liability for crimes specified in articles 13, 14 and 15 of the Law on Specialized Chambers and the Office of Specialized Prosecutor is sufficient to have committed only one prohibited action. So, only a special criminal act, whether murder, injury, rape etc. that had been committed over a civilian person during the period of time January 1, 1998-December 31, 2000 shall

\footnotetext{
${ }^{65}$ The Special Court, despite the fact was established by the Law, its activity represents cruel interference in Kosovo courts subject matter competence. The power of this court in relation to domestic courts makes it of supranational character and very questionable for criminal legal science.

${ }^{66}$ Salihu Ismet, Criminal Law, General Part, Prishtina, 2012, pg. 276.

${ }^{67}$ Elezi Ismet, Criminal Law of the Republic of Albania, Special Part I, Tirana, 1999, pg. 20.

${ }^{68}$ Hajdari Azem, War crimes against civilian population in Kosovo during the period of time Feruary 1998-June 1999, Prishtina, 2002, pg. 35.
} 
be criminally prosecuted and the person who had committed shall be punished by this court. It is sufficient that crime to be linked with the report of the Parliamentary Assembly of the Council of Europe which had been the object of criminal ivestigation by conducted by the Special Investigative Task Force of the Special Prosecution of the Republic of Kosovo.

The perpetrator of crimes determined in articles 13, 14 and 15 of the Law on Specialized Chambers and the Office of Specialized Prosecutor, in the first place shall be considered a person which directly had committed criminal actions specified in these articles. But, except the person which directly has undertaken criminal actions, as a perpetrator of these crimes shall be considered also the one which had planned, incited, ordered or in any other way had helped and gave support on planning, their preparation or execution. Consequently, in terms of ordering, as a perpetrator shall be considered only that person which according to the functioning position, had been able to order others in undertaking certain criminal actions, such is the case with superiors and military commanders.

Pursuant to article 16 paragraph 1 (b) the official position of defendant, whether the president of state, prime minister or member of government does not release him from criminal liability, neither does not mitigate the punishment. This is a pragmatic solution confirming once again the fact of equality of all citizens before the law. Also, neither the fact one of the actions or omissions that had been committed by a subordinate does not release his superior from criminal liability, if he knew or had reason to know that a subordinate intended to commit those actions or had committed and a superior did not take the necessary and reasonable measures to prohibit those actions, or to convict their perpetrators. In the concrete case, the principle of individual criminal liability shall be considered specifically. Finally, it must be emphasized the fact that the action of defendant in obeying the order of Government or to superior does not release him from criminal liability, but it may be taken into account concerning mitigation of punishment when it is required by the interest of justice.

\section{Principle non bis in idem}

This principle does not allow the repetition of a concluded trial with a final decision. ${ }^{69}$ It prohibits prosecution and punishment of a person for the criminal offence he had been convicted, acquitted or for which the indictment has been rejected by a final judgment. ${ }^{70}$

The principle non bis in idem is a basic principle also in the Special Court activity. Consequently, the concept of this principle the Law on

${ }^{69}$ Hajdari Azem, Legal aid and extradition, Prishtina, 2014, pg. 93.

${ }^{70}$ Compare: Jean Pradel, Geert Corstens, Gert Vermeulen, European Criminal Law, Tirana, 2010, pg. 76. 
Specialized Chambers and the Office of Specialized Prosecutor has extended in 3 segments (article 17):

1. First, nobody can be tried before another Kosovo court for offences he has been tried by Special Court;

2. Second, nobody can be tried by Special Court for offences he already had been tried by any Kosovo court; and

3. Nobody can be tried by Special Court for offences he already had been tried by International Criminal Tribunal for former Yugoslavia (ICTY).

Observed in the essence of these solutions easily could be ascertained the fact that the Special Court shall respect entirely the principle non bis in idem, but this principle shall be respected also by other courts, especially those operating in Kosovo. All this is in function of guaranteeing legal security of persons which faced before charges on crimes for which has been established the Special Court, but also to those which shall face concrete charges before this Court.

\section{The principle of non-recognition of amnesty acts}

Amnesty is an act, which in a form of law is issued by the highest state body-the assembly. Through amnesty unspecified persons by name shall be exempted from criminal prosecution, shall be exempted fully or partially from execution of the punishment, it shall be replaced the imposed punishment with a more lenient sentence or shall be assigned the remission of punishment from punished evidences. ${ }^{71}$ Amnesty in principle applies to all types of criminal offences. $^{72}$

Despite golas on basis of which amnesty has been provided as a manner of extinguishing punishments, it nevertheless does not constitute an act reflecting obligations for the Special Court and the possibility for its actions to be included in such an act. In fact, according to article 18 of the Law on Specialized Chambers and the Office of Specialized Prosecutor decisions of the Special Court shall not become subject to any type of amnesty provided by article 65 (150 of Constitution of the Republic of Kosovo. Also amnesty acts accorded to persons for an international crime, crimes resulted with severe bodily injury or death, or for any crime according to article 14 (2) of this law, if it is within within Special Court jurisdiction, shall not be an obstacle for their criminal prosecution or punishment.

\footnotetext{
${ }^{71}$ Salihu Ismet, Criminal Law, pg. 566.

${ }^{72}$ See more: Hajdari Azem § Hajdari Albulena, AMNESTY AS A SPECIFIC MANNER OF EXTINGUISHING PENALTIES WITH A SPECIAL FOCUS IN ITS ADDRESSING MANNER ACCORDING TO THE LAW NO. 04/L-209 ON AMNESTY OF KOSOVO, European Journal of Research in Social Sciences, Vol.3, No.5/ 2015, pg.19.
} 


\section{Jurisdiction of the Special Court}

By the Law on Specialized Chambers and the Office of Specialized Prosecutor to the Kosovo Special Court has been defined clearly subjectmatter, time, territorial, personal and simultaneous jurisdiction.

\section{Subject matter jurisdiction}

Through subject matter jurisdiction shall be determined the types of criminal offences that will be tried by the Special Court. These criminal offences provided in articles 12-16 of the Law on Specialized Chambers and the Office of Specialized Prosecutor. Such criminal offences are: 1) Crimes against humanity according to international law; 2) war crimes according to international law, including a) war crimes according to international law including serious violations of the Geneva Conventions of 1949; b) serious violations of the laws and customs of war in international armed conflicts known as such in international customary law and c) serious violations of applicable laws and customs in armed conflicts that are not of international character known as such in international customary law; and 3) other crimes according to Kosovo law including provided crimes in a) Criminal Law of of the Socialist Federal Republic of Yugoslavia (1976), b) Criminal Law of the Socialist Autonomous Province of Kosovo (1977); any criminal susbtantial law more lenient that has been in force from 1989 until October 27, 2000.

From a brief analysis conducted to these articles of the Law on Specialized Chambers and the Office of Specialized Prosecutor (12-16) easily can be achieved in these conclusions:

1. Kosovo Special Court within its mandate specified in the article 1 of this law shall be dealt with the adjudication of almost all actions which international law treats as crimes against humanity and war crimes;

2. Due to the fact international community in relation to Kosovo, the war of its people helped by NATO during the period of time February 1998June 1999 treates only as an armed conflict to the Special Court has been accorded the competence within war crimes (of course within jurisdiction determined in the article 1 of the law) to deal also with adjudication of severe violations of applicable laws and customs in armed conflicts that are not of international character;

3. Kosovo Special Court (within its mandate) shall be dealt with adjudication of crimes which were known by applicable legislation the so called non-discriminatory of former Yugoslavia, Province of Kosovo and the one issued by UN Mission (UNMIK) in Kosovo until 27 October, 2000;

4. To the Special Court has been accorded a mandate to adjudicate also other crimes, including post-war murders commited by political motives (which were not addressed so far by criminal justice institutions) as well as corruption criminal offences committed by senior political and state officials 
related to the period of time January 1, 1998-December 31, 2000, which constitutes a crowded different mysteries period of time concerning these crimes. $^{73}$

As it results to the Special Court has been accorded a very broad subject matter jurisdiction, perhaps even impossible to realized, bearing in mind general frameworks on which it is based its activity. Maybe this court as well as other international criminal courts established so far, as ad hoc courts by relevant mechanims of international community or under their pressure, as a primary mission shall have the establishment of interstate political balances than a noble mission that any court should have.

\section{Time jurisdiction}

Special Court similar as the International Criminal Tribunal of Nuremberg, Tokyo and The Hague Tribunal for the former Yugoslavia is an ad hoc court, established only for adjudication of crimes against humanity, war crimes and other crimes according to Kosovo law related to Report of the Parliamentary Assembly of the Council of Europe DOK 12462 dated January 7, 2012 which had been the object of criminal ivestigation by conducted by the Special Investigative Task Force of the Special Prosecution of the Republic of Kosovo. This means after concluding trials concerning these crimes this court shall cease operating. The Special Court shall adjudicate these crimes, as far as the same had been committed between the period of time January 1, 1998 and December 31, 2000. As it results, the Special Court has no mandate to adjudicate the similar crimes as long as they come out of this time frame. ${ }^{74}$

\section{Territorial jurisdiction}

Territorial jurisdiction determines the spatial limits of scope of authority of the Special Court. Observed in this aspect, this court, pursuant to article 8 of the Law on Specialized Chambers and the Office of Specialized Prosecutor has competences to adjudicate crimes specified in articles 12-16 which shall be considered to have been commenced or have been committed in Kosovo territory. As it results, the Special Court has the mandate to adjudicate crimes specified in these provisions, certainly as far as the same had been committed during the period of time January 1, 1998 and December 31, 2000, at any case when they commenced or had been

\footnotetext{
73 This is a period of time when were killed eminent personalities which developed their political activity within Democratic League of Kosovo. A pacifist party which was led by his spiritual leader Ibrahim Rugova.

${ }^{74}$ In fact, is alleged that crimes for adjudicating of which has been given a mandate to the Special Court in substance were committed exactly during the period of time January 1, 1998-December 31, 2000.
} 
committed in Kosovo, or commenced in Kosovo but had been committed in any other state., respectively had commenced in another state but had been committed in Kosovo. Therefore in order for Special Court to adjudicate any crime included in articles 12-16 of the Law on Specialized Chambers and the Office of Specialized Prosecutor it is mandatory to be related to Kosovo, respectively with persons and its territory.

\section{Personal jurisdiction}

Personal jurisdiction determines the category of persons which become subject of the Special Court authority. According to article 9 of the Law on Specialized Chambers and the Office of Specialized Prosecutor this court has a competence to adjudicate only natural persons and under no circumstances legal persons and state. In fact, in accordance with Kosovo courts active and passive personality jurisdiction according to applicable criminal laws which were in force between the period of time January 1, 1998 and December 31, 2000, and in addition to their territorial jurisdiction provided by the article 8, Special Court has jurisdiction over Kosovo citizenship persons or over persons who have committed crimes within their subject jurisdiction against Kosovo citizenship persons, wherever those crimes had been committed. Consequently, to the jurisdiction of this court become subject all persons, whether they are Kosovo citizens or not. It is esential that the victim of crime to be a citizen of Kosovo and the crime to have been committed within specified time limits.

\section{Simultaneous jurisdiction}

The Law on Specialized Chambers and the Office of Specialized Prosecutor (article 10) addresses the issue of modus operandi in cases when for a concrete criminal matter except the Special Court also other Kosovo courts conduct criminal proceedings. This legal provision makes it clear the fact that in such cases the Special Court has the advantage in comparison to other courts. In such situations the Special Court shall order the transfer of procedure within its jurisdiction. This possibility has to deal with instances at which shall be conducted criminal proceedings, including investigation. Transfer of the case can be required to be done by a prosecutor or another court, except the Constitutional Court, in Kosovo territory to Specialized Chambers and the Office of Specialized Prosecutor. In these terms transfer of the case include the trasnfer of any document, respectively all documents belonging the requested subject matter. The order of the Special Court on transfer is final and mandatory. The advantage of the Special Court, according to article 10 paragraph 2 of the Law on Specialized Chambers and the Office of Specialized Prosecutor had to deal also in relation to EULEX judges and prosecutors. This means that the Law No. 03/L- 053 on 
Jurisdiction and Competences of EULEX judges and prosecutors in Kosovo, does not apply to developing criminal cases before the Special Court and subject matters are object of any order to be transferred to this court.

\section{Organization and structure of the Special Court}

The Special Court according to article 24 of the Law on Specialized Chambers and the Office of Specialized Prosecutor consists of: 1) Specialized Chambers, including these bodies: a) Specialized Chambers, and: The Chamber of Basic Court, The Chamber of Court of Appeals, The Chamber of Supreme Court and the Chamber of Constitutional Court; and b) The Administrative Office including a) The Protection Office, The Office for Participation of Victims, b) The Office on Protection and Support of Witness, c) Victims Unit Management and d) Office of the Ombudsman; and 2) The Office of the Specialized Prosecutor that shall take mandate and personnel of the Special Investigative Task Force.

The Special Court shall adjudicate criminal case only through international judges. It shall act in individual and collegial composition. In individual composition decides a judge who conducts duties of pre-trial judge, ${ }^{75}$ and the judge if necessary performs other duties required by law. Whereas in collegial composition this court decides in panel of three judges, including a reserve judge before Basic Courts, in panel of Court of Appeals consisting of three judges, panels of Kosovo Supreme Court consisting of three judges and panels of Constitutional Court consisting of three judges.

Which shall be the number of international judges that shall be engaged in the Special Court currently is not been specified by a special act. However, the legislator requires that number of these judges should be such which ensures efficient functioning of specialized chambers.

Appointment of the Special Court judges shall be made by the Head of European Union Mission on Joint Security and Defense. Their appointment and of Presidents and Deputy-Presidents of the Specialized shall precede a selection which shall be made by a panel consisting of three international members who at least two of its members is required to be international judges with significant international experience in the criminal field. One of these two judges shall be appointed to be chair of the panel. The panel shall interview the competitive candidates, evaluate their performance and finalize by majority of votes the list with the names of candidates recommended for the position of a judge in Specialized Chambers

\footnotetext{
${ }^{75}$ Pre-trial judge according to in force legislation is a judge having competences during pretrial proceedings, especially during investigations. His competences have to deal with imposition of security measures to the defendant in criminal proceedings (for example detention on remand) and by providing material evidences in criminal procedure (control).
} 
and it presents to the Head of European Union Mission on Joint Security and Protection for appointment.

The Administrative Office is responsible to conduct administrative support services for Specialzied Chambers and to exercise other relevant responsibilities concerning with the mandate of the Protection Office, the Office for Participation of Victims, the Office on Protection and Support of Witness and the Office of Ombudsman.

The Office of the Specialized Prosecutor is responsible to conduct criminal investigations and exercise criminal prosecution for criminal offences which are part of the mandate of the Special Court.

Finally, it must be emphasized the fact that the Specialized Chambers and the Office of the Specialized Prosecutor except in Kosovo shall be functioning also in the Kingdom of Netherlands. Consequently is expectable that the main activity of the Special Court shall be conducted exactly in the Kingdom of the Netherlands. ${ }^{76}$

\section{Punishments that may be imposed by the Special Court}

According to article 44 of the Law on Specialized Chambers and the Office of Specialized Prosecutor the Special Court may impose a punishment by imprisonment, sentence to life imprisonment, punishment by fine, and the measure of confiscating assets.

When it comes to impose the punishment by imprisonment the Special court shall consider: a) the degree of punishment for that crime determined according to Kosovo law in the time of its commission, b) a more lenient punishment for that crime when this is foreseen by Kosovo law (punishment by fine), and c) article 7 (2) of the European Convention on Human rights and Fundamental Freedoms and Article 15 (2) of the International Covenant on civil and Political rights, included and protected in articles 22 (2), 22 (3) and 33 (1) of the Constitution of the Republic of Kosovo, and the extent to which the punishment of actions or omissions which were criminal according to the general principles of the law known by civilized nations would be prejudiced upon application of 2 (a) dhe (b).

Also, when it comes to imposing a punishment the Special Court shall take into account also mitigating and aggravating circumstances characterizing the case, the severity of crime and its consequences, as well as individual circumstances of the convicted person. ${ }^{77}$

Its punishments the Special Court shall impose by judgment. The judgment shall be rendered by a majority of votes of members of the panel. ${ }^{78}$

\footnotetext{
${ }^{76}$ Already a number of witnesses expected to testify before the Special Court of Kosovo, due to security reasons, have been transferred in third countries.

${ }^{77}$ Compare: Salihu Ismet, International Criminal Law, Prishtina, 2011, pg. 338.

${ }^{78}$ Krahaso: Sahiti Ejup, Justification in criminal proceedings, Prishtina, 1999, pg. 304.
} 
He shall be proclaimed publicly and it must be well justified. To the same it may be attached different or separate opinions. The rendered judgment on basis of standard procedure it may be appealed before the Court of Appeal and the Supreme Court. ${ }^{79}$ When there are allegations on violations of individual freedoms and rights guaranteed by this Constitution, concerning the rendered judgment the defendants and victims of crime may require its review from Specialized Chambers of the Constitutional Court. By a rendering judgment the Court shall order the convicted person to make a compensation of damage to the victims of crime, as well as shall order the measure of confiscating assets (property, incomes and assets) that were used in the commission of crime and derived from the commission of crime.

\section{Execution of punishments}

According to article 50 of the Law on Specialized Chambers and the Office of Specialized Prosecutor the punishment by imprisonment shall be executed in prisons of state which have accepted the jurisdiction of this court. In which of those countries shall be executed the punishment by imprisonment decide the President of the Specialized Chambers. ${ }^{80}$ The punishment by imprisonment shall be executed in accordance with state laws executing such punishment, but the Specialized Chambers are entitled to supervise the manner of its execution.

State entrusted the execution of punishment by imprisonment cannot release the convicted person before he would serve entirely the imposed punishment. Consequently, the duration of punishment can be modified, amended or changed only by a Special Court or arrangements accorded with it, if there is such for that goal according to article 60 of the Law on Specialized Chambers and the Office of Specialized Prosecutor.

\section{The Special Court cooperation with other Kosovo courts and entities and other states and international organizations}

According to article 53 of the Law on Specialized Chambers and the Office of Specialized Prosecutor all entities (courts, prosecution etc.) and persons in Kosovo shall be obliged to provide legal assistance and other assistance to the Special Court. They are obliged without any delay to respond in any submitted request by this Court dealing with assistance, enforcement order or decision such as could be the identification of persons, finding their whereabouts, interrogation of persons, protection of victims,

\footnotetext{
${ }^{79}$ Shegani Altin, Comparative Criminal Law, Tirana, 2005, pg. 133.

${ }^{80}$ It is expectable that execution of punishments by imprisonment imposed by the Special Court shall be made mainly in European Union countries, perhaps in another state but in which conditions of prisons mark the highest degree of compliance with international standards.
} 
preservation of evidences etc. In these terms, the legislator has determined that the Special Court has the advantage in proceeding criminal cases that are its subject matter jurisdiction, in comparison to all other Kosovo courts.

Therefore the Special Court shall order the transfer of procedures and investigations by another court and prosecution in Kosovo territory to the Specialized Chambers or the Office of Specialized Prosecutor.

Also, the Special Court may require assistance and cooperation also from another states, ${ }^{81}$ international organizations and other subjects when needed during investigations and prosecution of persons accused of crimes under its jurisdiction.

In these terms, the Special Court may use also agreements on mutual legal assistance concluded between Kosovo and other countries as well as to file a request by itself for such assistance based on principle of reciprocity. ${ }^{82}$

Finally it must be emphasized the fact that the Special Court shall have its own budget that does not derive from Kosovo budget and does not become subject of Auditor of Kosovo audit.

\section{Conclusion}

The modest results of this scientific paper have led me to the following conclusions:

1. The Special Court of Kosovo meets all the characteristics of an international criminal court. This due to the fact this court has its organizational structure except in Kosovo lying also in the Kingdom of Netherlands, it consists exclusively of international judges, it shall be financed by international funds, its punishments by imprisonment shall be executed outside of Kosovo etc.

2. The Special Court establishment, despite the needs that may have existed for it, it constitutes an injustice for Kosovo and its people. It is considered to be an injustice because Kosovo, as no where else in the world (by being a victim of war) is facing international justice twice for actions related with the same period of time, and once by the Hague Tribunal for the former Yugoslavia and now this Special Court.

3. The Special Court work is based in several fundamental justice principles such as: the principle of legality, the principle of individual

\footnotetext{
${ }^{81}$ In its cooperation with other states the Special Court should be attentive especially in relation to Serbia. Eventual evidences accepted by authorities of this state before the same can be used by relevant mechanisms of the Special Court they must become subject of a very professional verification.

${ }^{82}$ Direct requests for legal aid the Special Court of Kosovo may present in cases when Kosovo with that state has no agreement for legal assistance, as well as when the issue raised in the level of assistance is of a very confidential nature. In these cases requests shall be sent directly to the recipient.
} 
criminal liability, the principle ne bis in idem, the principle in dubio pro reo etc. These principles are of universal character and represent a guarantee for independent and objective work of this Court.

4. The Special Court has subject matter jurisdiction to adjudicate crimes against humanity according to international law; war crimes according to international law including severe violations of Geneva Conventions of 1949, severe violations of the laws or customs of war in international armed conflicts, known as such in customary international law and serious violations of the laws and customs applicable in armed conflicts not of an international character, recognized as such in the customary international law; as well as other crimes under the laws of Kosovo, including the crimes mentioned in: Criminal Law of the Socialist Federal Republic of Yugoslavia (1976), Criminal Law of the Socialist Autonomous Province of Kosovo (1977) and any more lenient substantial criminal law that it has been in force since 1989 until October 27, 2000.

5. The Special Court has jurisdiction over criminal offences within subject matter jurisdiction that had been committed in the period of time January 1, 1998-December 31, 2000. The Special Court shall deal with trial of these crimes as far as they have commenced or have been committed in Kosovo as well as this court shall adjudicate persons holding Kosovo citizenship and others who had committed crimes under its jurisdiction against persons holding Kosovo citizenship wherever those crimes could have been committed.

6. The Special Court consists of Specialized Chambers, The Office of Specialized Prosecutor and the Administrative Office. Organization and competences of these bodies are determined by law.

7. The Special Court through application of standard procedure as determined by the law, against perpetrators responsible of criminal offences may impose punishments of imprisonment, punishments of life imprisonment, punishments by fine and the measure of confiscating assets. Punishments by imprisonment of this court, as abovementioned, shall be executed in third countries which recognize its jurisdiction. The Special Court shall cooperate with institutions (courts, prosecution etc.) and other persons in the country and abroad (states and international organizations etc.). Local institutions are legally obliged to act according to requirements of this court, because it has supermacion to all country institutions. The Special Court may issue orders on transfer of criminal prosecution and proceedings from any local court and prosecution towards it, and they are obliged to act according to these orders and to submit all documents concerning these cases. 


\section{References:}

Agreement on the Organisation of the Institution of Kosovo Special Court and its relocation to the Netherlands.

Elezi Ismet, Criminal Law of the Republic of Albania, Special Part I, Tirana, 1999.

Hajdari Azem § Hajdari Albulena, Amnesty as a specific manner of extinguishing penalties with a special focus in its addressing manner according to the law No.04/L-209 on amnesty of Kosovo, European Journal of Research in Social Sciences, Vol.3, No.5/ 2015.

Hajdari Azem, Certain Successes and Failures of the UN Mission in Kosovo in Managing the Criminal Justice System, Studia, Universitatis Babes Bolyai, Politica, No.1.2008.

Hajdari Azem, Criminal Procedure Law, General Part, Prishtina, 2014.

Hajdari Azem, Legal aid and extradition, Prishtina, 2014.

Hajdari Azem, The functinalization role of criminal justice system in north in estabilishing sustaniable peace in Kosovo and Balkan Region, American Research Throughts, Volume 1, Issue 2, 2014.

Hajdari Azem, War crimes against civilian population in Kosovo during the period of time Feruary 1998-June 1999, Prishtina, 2002.

HajdariAzem dhe Albulena Hajdari, Functionality of the Criminal JusticeSystem in Kosovo, with Special Focusof the Northern Partof the Country, in the Lightof the Agreementof Brusselsof 19 April, 2013 for the Normalization of the Relations between Kosovo and Serbia, EUROPEAN ACADEMIC RESEARCH, Vol. I, Issue 12/ March 2014..

Jean Pradel, Geert Corstens, Gert Vermeulen, European Criminal Law, Tirana, 2010.

Koha.net//?id=27§=69212.

Law on Specialized Chambers and the Office of Specialized Prosecutor )Law No. DL-027/2015).

Sahiti Ejup §Murati Rexhep Criminal Procedure Law, General Part, Prishtina, 2014.

Sahiti Ejup, Justification in criminal proceedings, Prishtina, 1999.

Salihu Ismet, Criminal Law, General Part, Prishtina, 2012,.

Salihu Ismet, International Criminal Law, Prishtina, 2011.

Shegani Altin, Comparative Criminal Law, Tirana, 2005. 